DOI: https://doi.org/10.33330/jurteksi.v5i1.296

Available online at http://jurnal.stmikroyal.ac.id/index.php/jurteksi

\title{
SISTEM INFORMASI TATA KELOLA PENDAFTARAN KONTRAK CAFETARIA DAN RESTORAN PT. ANGKASA PURA II BANDARA MINANG KABAU
}

\author{
Dewi Anggraeni \\ Sistem Informasi, STMIK Royal Kisaran \\ Email: anggraeni1987@gmail.com
}

\begin{abstract}
Information systems for processing data on registration of contracts for cafeterias and restaurants regulate all the needs of system users, as well as presenting needed and effective reports. The information system for processing data on registration of contracts for cafeterias and restaurants has data entry for tenants, places, cafeteria and restaurant management, and contract registration, tenant data search process, and cafeteria and restaurant contract data search process and produces list of tenant names, cafe per contract report month, cafeteria and restaurant contract report per year where all the processes were done manually beforehand.
\end{abstract}

Keywords: Information System, Cafeteria and Restaurant Contract Registration, PT. Angkasa Pura II

\begin{abstract}
Abstrak: Sistem informasi pengolahan data tata kelola pendaftaran kontrak Cafetaria dan Restoran mengatur semua kebutuhan pengguna sistem, serta menyajikan laporan-laporan yang dibutuhkan dengan efektif dan efesien. Sistem informasi pengolahan data tata kelola pendaftaran kontrak Cafetaria dan Restoran memiliki entri data penyewa, tempat, manajemen cafetaria dan restoran, dan pendaftaran kontrak, proses pencarian data penyewa, dan proses pencarian data kontrak cafeteria dan restoran serta menghasilkan daftar nama penyewa, laporan kontrak cafe per bulan, laporan kontrak cafetaria dan restoran per tahun yang dimana semua proses tersebut dikerjakan secara manual sebelumnya.
\end{abstract}

Kata kunci: Sistem Informasi, Pendaftaran Kontrak Cafetaria dan Restoran, PT. Angkasa Pura II

\section{PENDAHULUAN}

PT. Angkasa Pura II (Persero) berlokasi di Bandara Minang Kabau, salah satu perusahaan yang memiliki beberapa wadah cafetaria dan restoran. Wadah-wadah tersebut dikontrakan kepada masyarakat yang ingin mengembangkan usahanya dan merupakan salah satu sumber yang memberikan profit lebih untuk PT. Angkasa Pura II.

Dalam pengembangan pengelolaan cafetaria dan restoran PT.
Angkasa Pura II (Persero) membutuhkan sebuah sistem informasi untuk penataan pandaftaran penyewaan wadah, dimana sistem yang berlangsung dalam pengolahan data pendaftaran tersebut dilakukan menggunakan sistem manual dengan cara mencatat dengan tulisan tangan pada lembaran-lembaran kertas.

Restoran merupakan salah satu bidang usaha yang mendukung perkembangan industri pariwisata[1].

Pada sistem yang sedang berjalan saat ini, terjadinya kesulitan 
DOI: https://doi.org/10.33330/jurteksi.v5i1.296

Available online at http://jurnal.stmikroyal.ac.id/index.php/jurteksi

dalam pengecekan atau pencarian data, terkait pada laporan-laporan yang ada. Setiap terjadi sebuah keraguan data dalam sebuah laporan, pihak staf administrasi harus membolak balikan lembaran-lembaran kertas yang menumpuk, karena laporan tersebut disimpan dalam bentuk dokumen dalam sebuah map dokumen.

Sistem yang sedang berjalan saat ini, mengunakan media yang sangat terbatas dalam menjangkau historis penyewaan wadah. Disaat pihak pimpinan ingin meminta keterangan secara langsung pada pihak staf administrasi, pimpinan harus menunggu dalam waktu tidak kurang dari 10-20 menit untuk menerima jawaban, karena keterangan tersebut berada pada laporan-laporan yang menumpuk dalam satu dokumentasi. Sistem ini kurang efektif dan tidak efesien dalam pembuatan laporan. Dalam pencatatan selama ini dokumentasi yang ada, dijadikan langsung kebentuk laporan-laporan dan laporan-laporan tersebut diserahkan pada pimpinan. Pembuatan laporan dilakukan secara berulangulang pada masing-masing laporan yang berbeda.

Berdasarkan pengamatan yang dilakukan pada PT. Angkasa Pura II (Persero), maka dapat diidentifikasi berberapa permasalahan, yaitu: belum tersedianya aplikasi sistem informasi pengolahan data tata kelola pendaftaran kontrak cafetaria dan restoran pada PT. Angkasa Pura II. Terjadinya kesulitan dalam pengecekan atau pencarian data, terkait pada laporan-laporan yang ada. Media yang digunakan dalam menjangkau historis penyewaan cafetaria dan restoran berupa dokumen, sehingga sistem ini kurang efektif dan tidak efesien dalam pembuatan laporan.

Adapun tujuan dari penelitian ini adalah untuk merancang aplikasi sistem informasi pengolahan data tata kelola pendaftaran kontrak cafetaria dan restoran pada PT. Angkasa Pura II (Persero) Bandara Minang Kabau.

Sistem informasi adalah suatu sistem di dalam suatu organisasi yang mempertemukan kebutuhan pengolahan transaksi harian yang mendukung fungsi operasi organisasi yang bersifat manajerial dengan kegiatan strategi dari suatu organisasi untuk dapat menyediakan kepada pihak luar tertentu dengan laporanlaporan yang diperlukan[2][3][4].

Sistem informasi pengolahan data tata kelola pendaftaran kontrak cafetaria dan restoran pada PT. Angkasa Pura II (Persero) Bandara Minang Kabau diharapkan dapat mengatasi masalah yang ada pada sistem yang lama sehingga mampu memenuhi semua kebutuhan sistem. Pada aliran sistem informasi yang baru ini terdapat beberapa perubahanperubahan, dan perubahan dari proses yang dilakukan secara manual menjadi proses yang dilakukan secara komputerisasi.

Sistem ini dapat mengentrikan data, menyimpan dan memproses data tata kelola pendaftaran kontrak serta menghasilkan laporan sehingga dengan adanya program aplikasi ini, informasi tata kelola pendaftaran kontrak yang dihasilkan menjadi lebih akurat dan dapat mengurangi tingkat kesalahan. Adapun laporan yang dihasilkan pada aplikasi ini adalah daftar nama penyewa cafeteria dan restoran, laporan kontrak cafetaria dan restoran per bulan, laporan kontrak 
DOI: https://doi.org/10.33330/jurteksi.v5i1.296

Available online at http://jurnal.stmikroyal.ac.id/index.php/jurteksi

cafetaria dan restoran per tahun, kwitansi pembayaran, dan surat kontrak

\section{METODE}

Beberapa langkah yang peneliti lakukan agar tujuan penelitian ini tercapai, yaitu: 1) Identifikasi dan Analisis Masalah. 2) Menentukan Tujuan. 3) Mempelajari Literatur.

Teknik pengumpulan data dilakukan dengan 3 cara, yaitu: 1) Wawancara dan Angket. 2) Observasi langsung pada sistem yang sedang berjalan pada PT. Angkasa Pura II. 3) Semua data yang berkaitan dengan objek penelitian yang diperoleh dari hasil wawancara, angket (kuisioner), dan observasi akan didokumentasikan untuk dijadikan bahan referensi kelanjutan penelitian.

\section{HASIL DAN PEMBAHASAN}

Adapun aliran dari sistem informasi pengolahan data tata kelola pendaftaran kontrak cafetaria dan restoran pada PT. Angkasa Pura II (Persero) Bandara Minang Kabau adalah sebagai berikut:

1. Penyewa menyerahkan data penyewa, tempat, dan pendaftaran kontrak ke staf administrasi.

2. Staf adminitrasi memproses data yang sudah diperoleh dari penyewa dengan menggunakan aplikasi Microsoft Excel.

3. Data yang sudah diolah menghasilkan laporan-laporan berupa daftar penyewa cafeteria dan restoran, laporan kontrak cafetaria dan restoran per bulan, laporan kontrak cafetaria dan restoran per tahun, kwitansi pembayaran, surat kontrak, dan laporan status tempat.

4. Laporan diserahkan ke dipimpinan untuk di ketahui dan ditandatangani.

5. Laporan yang sudah ditandatangani, diarsipkan oleh pimpinan satu rangkap dan satu rangkap untuk staf administrasi.

6. Kwitansi dan surat kontrak diberikan kepada penyewa satu rangkap.

Untuk lebih jelasnya dapat dilihat pada Gambar 1 berikut ini:

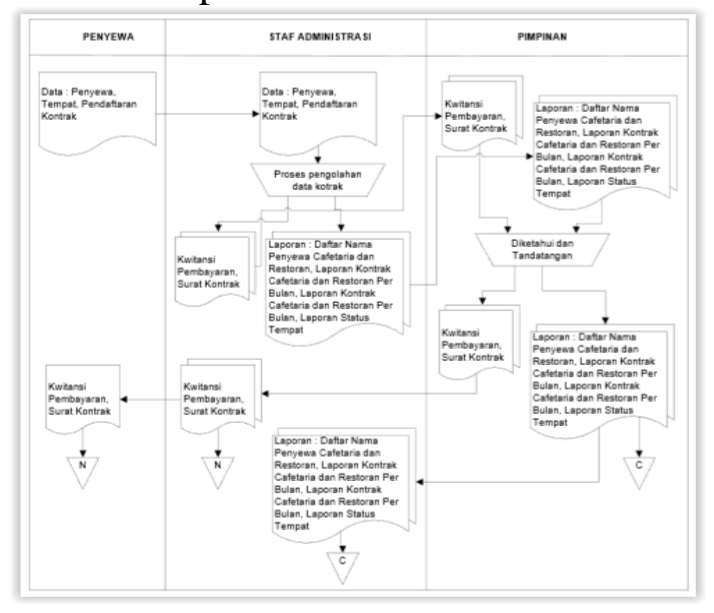

Gambar 1. Aliran Sistem Pengolahan Data Tata Kelola Pendaftaran Kontrak Cafetaria dan Restoran

Analisis yang dapat dilakukan pada sistem di atas, diuraikan sebagai berikut:

1. Belum tersedianya program aplikasi dalam mengolah data Tata Kelola Pendaftaran Kontrak Cafetaria dan Restoran.

Dalam mengolah data-data Tata Kelola Pendaftaran Kontrak Cafetaria dan Restoran, sistem yang digunakan berupa aplikasi Microsoft Excel. Aplikasi seperti ini membutuhkan waktu lebih lama untuk menyelesaikan proses pengolahan data.

Oleh karena itu pembangunan 
Available online at http://jurnal.stmikroyal.ac.id/index.php/jurteksi

aplikasi Sistem Informasi Pengolahan Data Tata Kelola Pendaftaran Kontrak Cafetaria dan Restoran sangat penting, karena dapat mengatasi permasalahan yang terjadi, sehingga proses pengolahan data dapat berjalan dengan lebih efektif dan efesien.

Kesulitan dalam penyajian informasi yang dibutuhkan karena informasi disimpan dalam bentuk file atau arsip.

Sistem dinilai tidak memberikan jaminan untuk ketersediaan datadata yang sudah ada, karena dengan melakukan pengarsipan berbetuk file sangat besar kemungkinan data-data tersebut akan hilang, selain itu akan terjadi kesulitan untuk pencarian data, karena penumpukan file-file tersebut.

\section{Hierarchy Input Process Output (HIPO)}

HIPO merupakan penggambaran lebih lanjut tingkatan-tingkatan proses input atau output dari data flow diagram untuk dijadikan sebagai modul dalam pembuatan program.

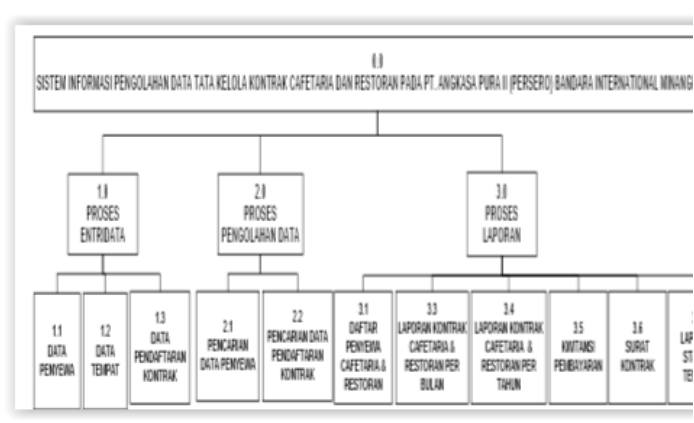

Gambar 2. HIPO Sistem

Informasi Pengolahan Data Tata

Kelola Pendaftaran Kontrak

Cafetaria dan Restoran

\section{Context Diagram (CD)}

Diagram ini adalah diagram level tertinggi (zero level) dari Data Flow Diagram (DFD) yang menggambarkan hubungan sistem dengan lingkungan luarnya.

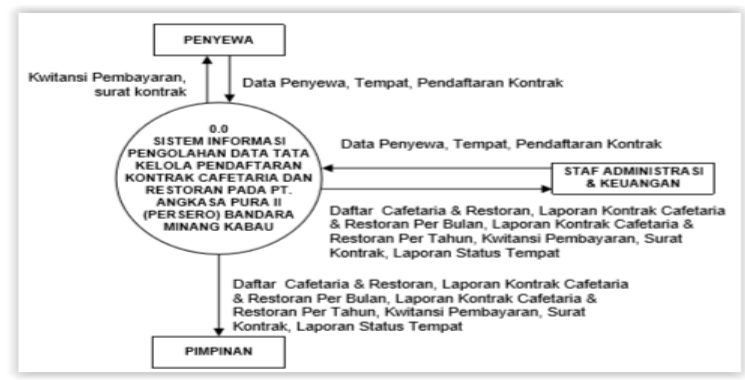

Gambar 3. Context Diagram (CD)

Sistem Informasi Pengolahan Data

Tata Kelola Pendaftaran Kontrak

Cafetaria dan Restoran

Entity Relationship Diagram (ERD)

Entity Relationship

Diagram(ERD) merupakan hubungan antara entity-entity yang terdapat dalam suatu database.

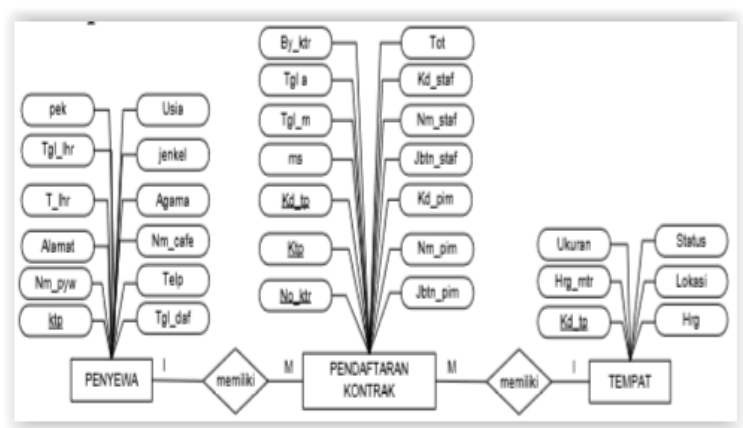

Gambar 4. Entity Relationship

Diagram (ERD) Sistem Informasi

Pengolahan Data Tata Kelola

Pendaftaran Kontrak Cafetaria dan

Restoran

Dalam merancang sistem informasi pengolahan data tata kelola pendaftaran kontrak cafetaria dan restoran pada PT. Angkasa Pura II (Persero) Bandara Minang Kabau, proses yang dilakukan, yaitu Total Biaya Kontrak = Total Biaya Kontrak + Biaya Kontrak 
DOI: https://doi.org/10.33330/jurteksi.v5i1.296

Available online at http://jurnal.stmikroyal.ac.id/index.php/jurteksi

\section{Menu Utama}

Menu Utama merupakan kerangka dasar dari beberapa sub program yang ada didalamnya sebagai tampilan utama dari program sistem informasi pengolahan data tata kelola pendaftaran kontrak cafetaria dan restoran pada PT. Angkasa Pura II (Persero) Bandara Minang Kabau.

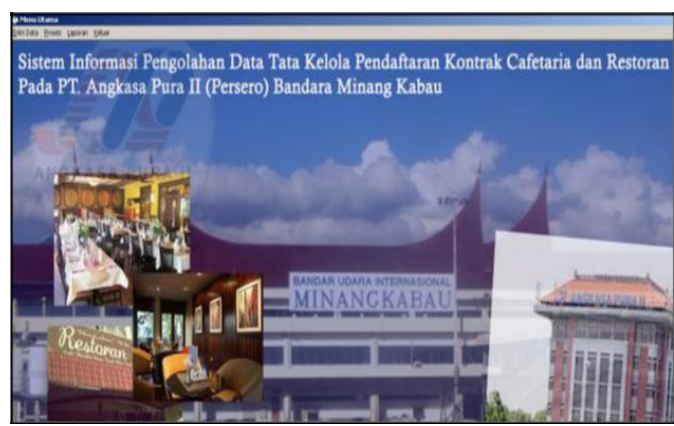

Gambar 5. Menu Utama

\section{Form Data Penyewa}

Form ini merupakan form untuk mengentrikan data penyewa. Dalam form ini dirancang beberapa tombol yaitu tambah, simpan, koreksi, hapus, dan keluar. Tombol tambah dan tombol simpan berfungsi menambah dan menyimpan data penyewa yang dientrikan. Tombol koreksi berfungsi memperbaiki data yang salah. Tombol hapus berfungsi menghapus data-data yang ada. Tombol keluar berfungsi sebagai perintah keluar dari form.

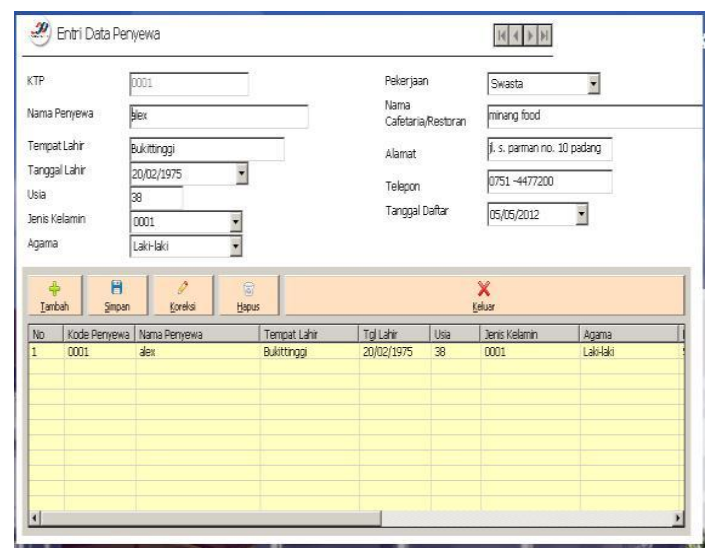

Gambar 6. Form Data Penyewa

\section{Form Data Tempat}

Form ini merupakan form untuk mengentrikan data tempat. Dalam form ini dirancang beberapa tombol yaitu tambah, simpan, koreksi, hapus, dan keluar. Tombol tambah dan tombol simpan berfungsi menambah dan menyimpan data tempat yang dientrikan. Tombol koreksi berfungsi memperbaiki data-data yang salah. Tombol hapus berfungsi menghapus data-data yang ada. Tombol keluar berfungsi sebagai perintah keluar dari form.

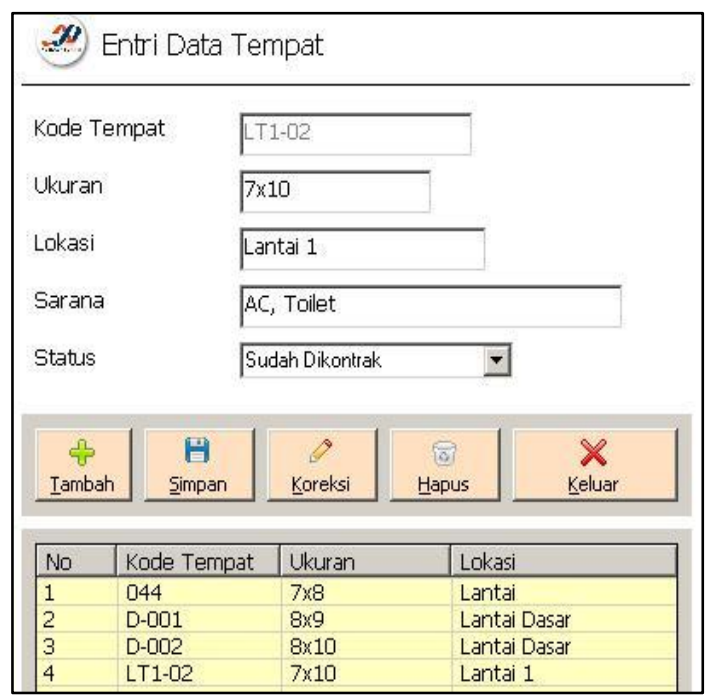

Gambar 7. Form Data Tempat

\section{Form Data Pendaftaran Kontrak}

Form ini merupakan form untuk mengentrikan data pendaftaran kontrak. Dalam form ini dirancang beberapa tombol yaitu tambah, simpan, koreksi, hapus, dan keluar. Tombol tambah dan tombol simpan berfungsi menambah dan menyimpan data pendaftaran kontrak yang dientrikan. Tombol koreksi berfungsi memperbaiki data yang salah. Tombol hapus berfungsi menghapus data yang ada. Tombol keluar berfungsi sebagai perintah keluar dari form. 
Available online at http://jurnal.stmikroyal.ac.id/index.php/jurteksi

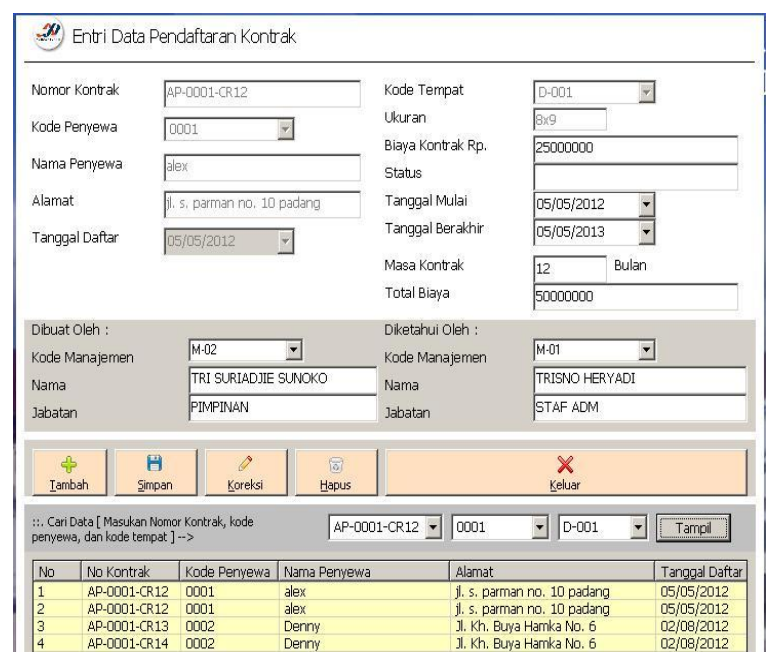

Gambar 8. Form Pendaftaran Kontrak

\section{Form Proses Pencarian Data}

\section{Penyewa}

Form ini merupakan form pencarian data penyewa. Dalam form ini dirancang dua tombol yaitu cari dan tombol. Tombol cari berfungsi untuk mencari data penyewa dan Tombol keluar berfungsi sebagai perintah keluar dari form.

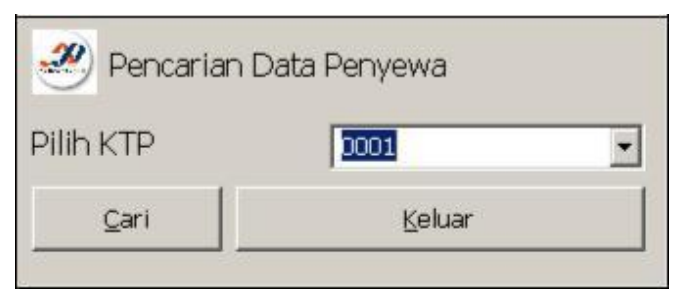

Gambar 9. Form Proses Pencarian

Data

Penyewa

\section{Form Proses Pencarian Data Pendaftaran Kontrak Cafetaria dan Restoran}

Form ini merupakan form pencarian data kontrak cafetaria dan restoran. Dalam form ini dirancang dua tombol yaitu cari dan tombol cari berfungsi untuk mencari data kontrak cafetaria dan restoran dan Tombol keluar berfungsi sebagai perintah keluar dari form

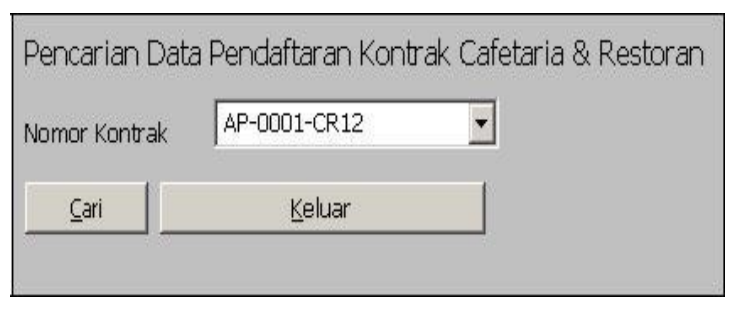

Gambar 10. Form Proses Pencarian

Data Pendaftaran Kontrak Cafetaria dan Restoran

\section{Daftar Penyewa Cafetaria dan}

\section{Restoran}

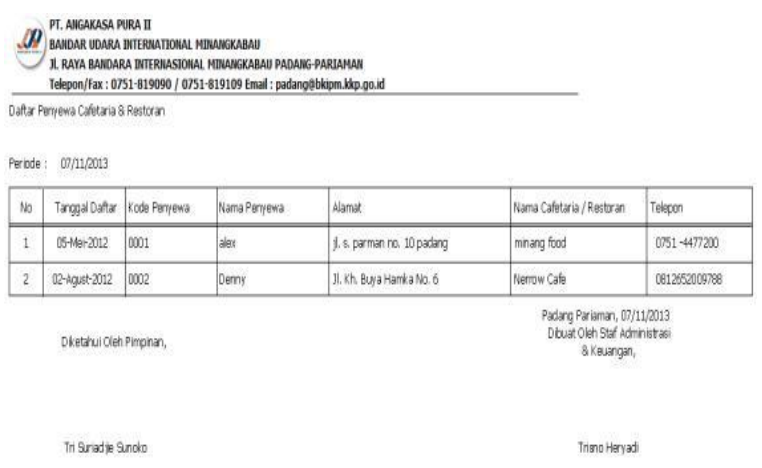

Gambar 11. Daftar Penyewa Cafetaria dan Restoran

\section{Laporan Kontrak Cafetaria dan Restoran Per Bulan}

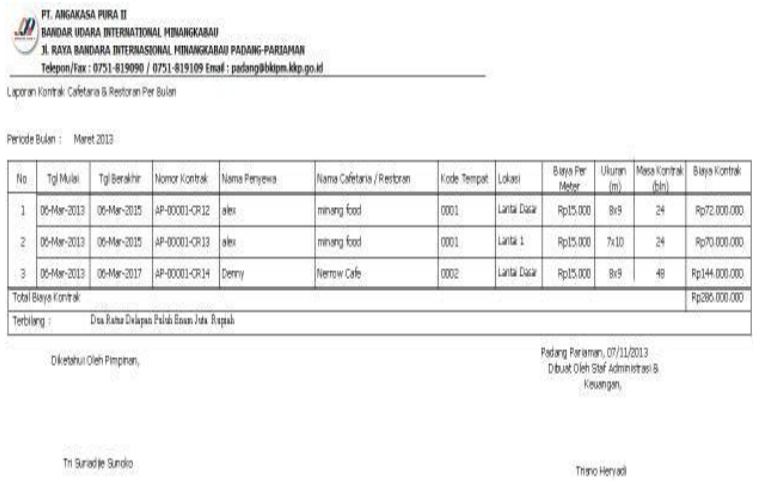

Gambar 12. Laporan Kontrak

Cafetarian dan Restoran Per Bulan

\section{Laporan Kontrak Cafetaria dan} Restoran Per Tahun 
DOI: https://doi.org/10.33330/jurteksi.v5i1.296

Available online at http://jurnal.stmikroyal.ac.id/index.php/jurteksi

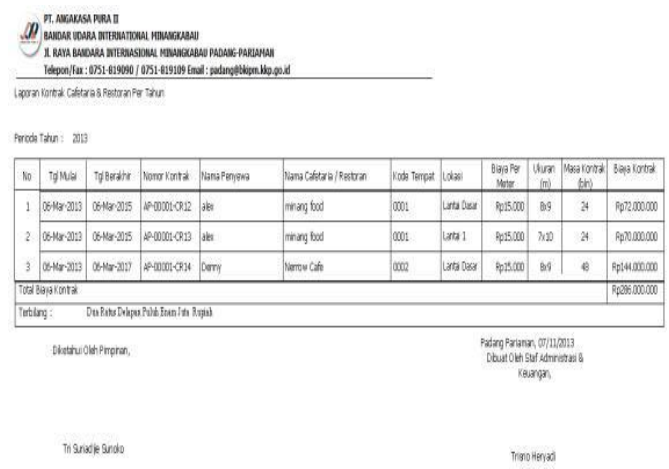

Gambar 13. Laporan Kontrak Cafetarian dan Restoran Per Tahun

\section{Kwitansi Pembayaran}

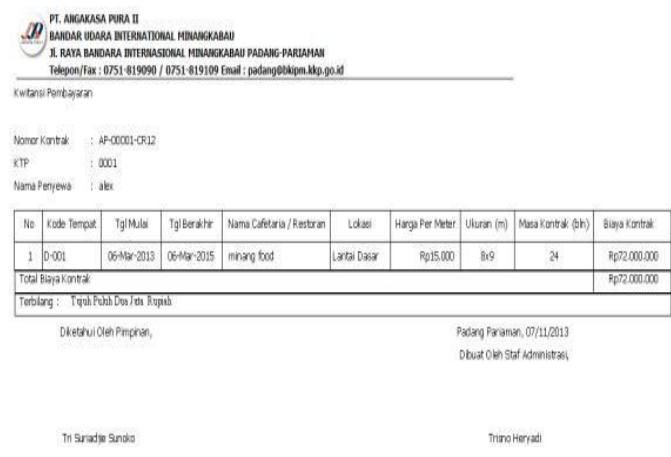

Gambar 14. Kwintansi Pembayaran

\section{Surat Kontrak}

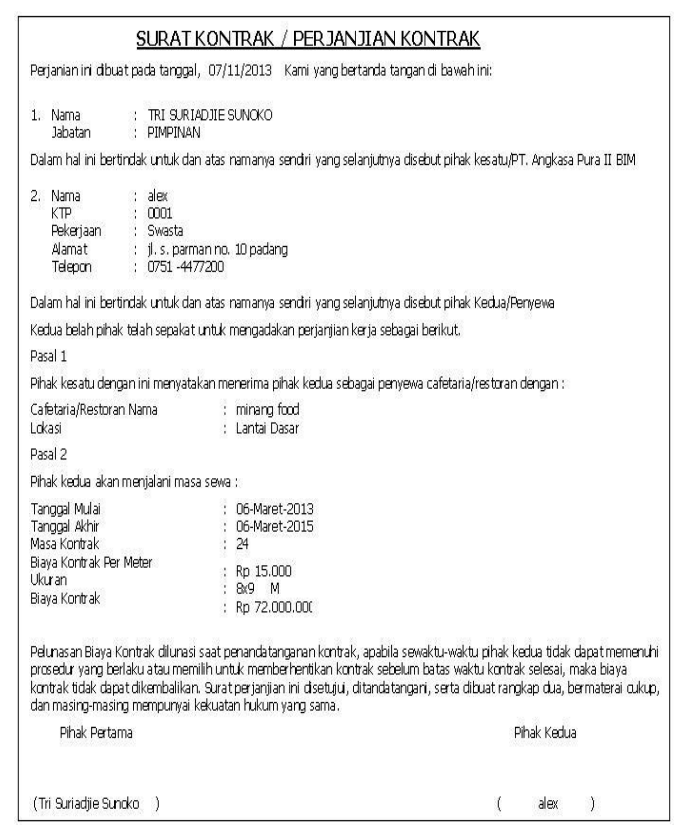

Gambar 15. Surat Kontrak

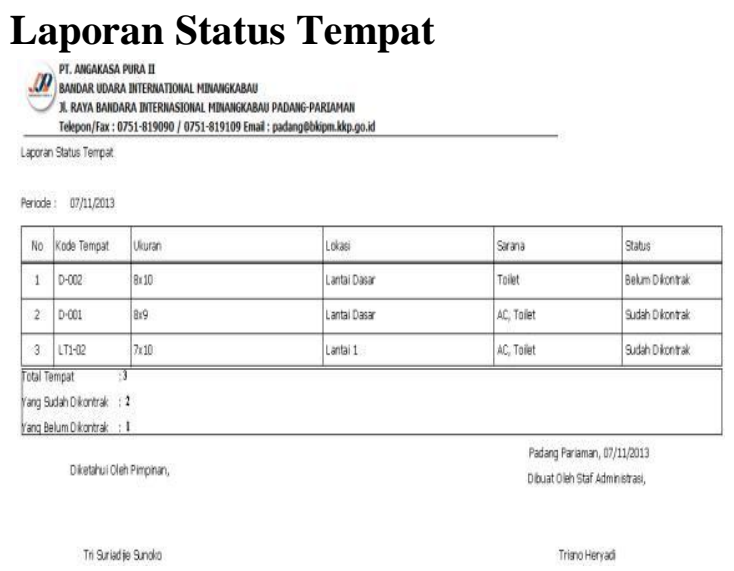

Gambar 16. Laporan Status Tempat

\section{SIMPULAN}

Berdasarkan pembahasan yang telah dilakukan pada bab-bab sebelumnya, maka dapat diambil kesimpulan, 1) Sistem Informasi pengolahan data tata kelola pendaftaran kontrak cafetaria dan restoran pada PT. Angkasa Pura II (Persero) Bandara Minang Kabau berguna membantu kinerja perusahaan dalam hal pengolahan data tata kelola pendaftaran kontrak cafetaria dan restoran. 2) Sistem informasi ini memudahkan dalam proses pengecekan atau pencarian data yang dibutuhkan terkait pada laporan daftar nama penyewa cafeteria dan restoran, laporan kontrak cafeteria dan restoran per tahun, kwitansi pembayaran, surat kontrak, dan laporan status tempat.

\section{DAFTAR PUSTAKA}

[1] P. N. F. Agoes A, "KAJIAN PUSTAKA MENGENAI RESTAURANT

ATMOSPHERE." pp. 110-116, 2015.

[2] Rizaldi. R, "Penerapan Waterfall Dalam Membangun Sistem 
DOI: https://doi.org/10.33330/jurteksi.v5i1.296

Available online at http:/jurnal.stmikroyal.ac.id/index.php/jurteksi

Informasi Pengolahan Data," vol. IV, no. 1, pp. 71-80, 2017.

[3] D. Anggraeni, R. Rahim, and A. Z. Syah, "Decision Support System For Formula Milk Selection Based On Nutrition Value Using Tahani Model Database Fuzzy Method Decision Support System For Formula Milk Selection Based On Nutrition Value Using Tahani Model Database Fuzzy Method," 2018.

[4] R. R. Yuma. Febby Madona, "DI PERGURUAN TINGGI DENGAN METODE PROFILE MATCHING Implementasi Sistem Implementasi User Interface Implementasi user interface dilakukan," vol. 9986, no. September, pp. 3-6, 2018. 